\title{
Transformation of Transmigration Areas as Ethnic Political Identity (A Study of Javanese Ethnicity in Pringsewu Regency, Lampung Province)
}

\author{
Junaidi Junaidi 1,* Suwarno Suwarno ${ }^{2,}$ Frans Salsa Romando ${ }^{3}$ \\ 1,2,3, Department of Sociology, Faculty of Social and Political Sciences, University of Lampung, Indonesia 1 \\ *Corresponding author. Email: junaidi@fisip.unila.ac.id
}

\begin{abstract}
The birth of Pringsewu district which is a transemigrant area on the island of Sumatra signifies the emergence of a new political movement characterized by ethnicity. Pringsewu Regency was born by ethnic immigrants without any community friction that led to violent conflict. Pringsewu Regency, which used to be a transmigrant area, was able to transform into an area that could be seen as a political identity owned by the Javanese. Therefore, the ability of ethnic Javanese who are transmigrants in building their own administrative area at the district level is interesting to study in the academic realm. The aim is to provide an overview of the success of ethnic Javanese in gathering political movements, so that they can establish Pringsewu district without physical violence. This study uses a qualitative method with a case study approach. This study results that the transformation of the Javanese ethnic movement in building and establishing Pringsewu Regency is an integrative form of Javanese ethnic political identity. Integration is created through social exchanges carried out between ethnic groups, especially Javanese and Lampung ethnic groups. Therefore, the birth of Pringsewu district is a manifestation of the transmigrant community movement in the transmigration area through the community integration instrument formed through social exchange.
\end{abstract}

Keywords: Transformation, Transmigration, Political Identity, Javanese Ethnicity, pringsewu district.

\section{INTRODUCTION}

Human migration seems to be a natural thing that is always done. The movement of humans or communities to an area is part of a way and a way to survive. In the reality of the history of the Indonesian nation, the displacement or migration carried out by the Indonesian people began normatively when the Dutch implemented ethical politics in the colonies, including in Indonesia [1]. This movement makes social changes occur in society [2] The application of ethical politics carried out by the Dutch at that time provided opportunities for population movement to all regions in Indonesia. One of the communities affected by ethical politics is the Javanese Ethnic community, who was moved to Lampung, Sumatra.

Basically, this displacement was initially shown as a way for the Dutch to contain upheaval on the island of Java at that time [3]. In addition, the Netherlands also needed workers to open plantations in other areas, including on the island of Sumatra. Thus, the Javanese Ethnic community was chosen as the workforce while at the same time holding back the upheaval of resistance on the island of Java, as well as implementing ethical politics on the other side [2]. After independence, this transmigration policy was still carried out by the Indonesian government. This policy applies nationally and is under the supervision of the Director General of Transmigration at that time. One of the policies is to continue to choose Lampung as a transmigration area outside Java [4]; [1]; [2].

The displacement of Javanese ethnicity to the Sumatra region had a major effect on the population in the Lampung area. This change in population has a major impact on the social dynamics of the community. This migration also has a direct impact on ethnic diversity and the increase in other ethnic groups in the Lampung Province area, so this has a huge impact on all lines of community life. In addition, the presence of 
ethnic immigrants who are able to adapt well in the transmigration area provides an illustration of the success in managing their transmigration.

The success of the province in managing its transmigration can be seen how the transmigrant community, who are migrants from outside the region, can acculturate and even assimilate with the immigrant population. In fact, it is able to create nuances of interdependence between different ethnic groups in society. In addition, demographically, the number of immigrants is much higher than the original population (see Pringsewu Regency Central Statistics Agency, 2019). Of course that's not all, success is not only related to demography, even in the political, economic, and other aspects, the transmigrant community has succeeded in developing itself.

One of the most visible successes from the displacement of ethnic and population populations overseas on the island of Sumatra, namely the formation of Pringsewu Regency as a regency which by name and ethnicity is mostly occupied by Javanese ethnicity. Thus, it is not uncommon to mention that Pringsewu Regency is a district owned by ethnic Javanese outside Java [5]. The existence of Pringsewu Regency, which by name and the majority of the population is identical with Javanese Ethnicity, provides a separate picture that, it is necessary to study the political identity of the Javanese Ethnic in Pringsewu Regency, Lampung Province.

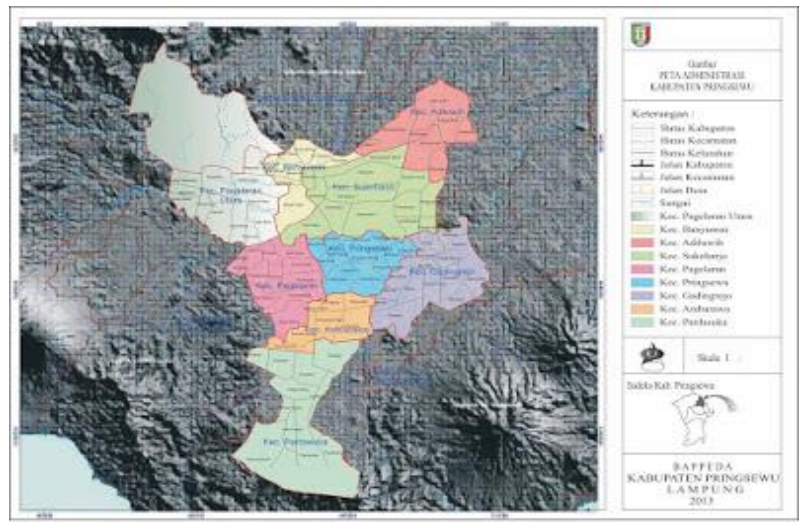

Figure 1 Map of Pringsewu . Regency

(Source: BPS Pringsewu Regency, 2020)

From previous studies on identity politics or on ethnicity, no one has been able to describe political identity from the perspective of identity politics. So far, the study of politics is more about the study of identity politics. Thus, previous political studies looked at the level of identity politics which were seen as political studies in the science of government or identity politics at a practical level (See [6]; [7]; [8]; [9]; [10]; [11]; [12]; [2]). Therefore, there are no studies of identity politics that discuss identity politics that is able to explain the transformation of transmigrant areas as the political identity of Javanese ethnicity as transmigrants.

In addition, in the study of transmigration, there has been no study of the transformation of the transmigration area that is able to give birth to a broader political identity. Previous studies only discussed transmigration at the level of dynamics and the transmigration process. In addition, it only discusses the dynamics of the life of the transmigrant community on a local and national scale (see [4]; [13]; [14]; [1]). Therefore, no one has studied transmigration in the realm of politics or political identity. Seeing this, a study on the transformation of transmigrant areas as an ethnic political identity really needs to be done in the field of social and political science. Thus, providing updates in social and political science studies.

Seeing this, a study of the transformation of transmigrant areas as a political identity is very necessary in social and political science. In addition, this study is also a study of migration (Transmigration). So that it provides updates in social and political science studies, as well as studies on social migration of the community, especially regarding transmigration studies.

\section{METHOD}

The research method used in this study is a qualitative method with case study analysis. The cases are analyzed on how the transmigrant community (ethnic Javanese) in the Pringsewu area was able to create an administrative area characterized by ethnicity or Javanese ethnicity, without losing the original identity of the area.

In addition, this study selected the Pringsewu Regency area because the area was a transmigrant area which later turned into an administrative district level area. In addition, this area is the only regency area that can be created by the transmigrant community movement which is directly supported by the original inhabitants of the transmigration area, namely the Lampung Ethnic. Therefore, this study focuses on how these different tennis movements can result in governance in Pringsewu Regency.

Sources of data in this study that comes from primary and secondary data. Primary data was obtained from the activities of collecting data sources directly in the field, such as interviews and observations. Interviews were conducted with a number of Javanese and Lampung ethnic groups from various regions in Pringsewu. In addition, interviews were conducted with several other ethnic groups as well as residents from other districts as a comparison and to strengthen the conclusions from the interviews. Interviews with ethnic Javanese, Lampung, other ethnic groups (Sunda, Bali, Palembang) or residents of other districts were conducted in an unstructured manner until the data sought was saturated. Interviews were conducted regarding how the dynamics of transmigration and their political views on the ability of Javanese ethnicity to form an administrative area at the district level in the transmigration area. 
Observational data collection was carried out by making observations at the center of government, as well as several indigenous areas, namely the Lampung ethnicity and the immigrant population, namely the Javanese ethnicity. things that are analyzed from the results of this observation, namely about how the symbols and jargon of the district of Pringsewu. Then how about the customary process, economic transactions, to the farming style of the people in the Pringsewu district. This is done to conclude the extent of acceptance of indigenous and immigrant ethnic groups in Pringsewu district.

Then, in this study an analysis was also carried out on documentation data (photos, pictures, books, regional profiles, books, journals, videos, etc.) obtained related to the dynamics of the integration of migrant areas, and documentation related to the formation of transmigration areas, as well as documentation related to the regional archives of the pringsewu district.

This research is also supported by quantitative data obtained from secondary data from the Central Bureau of Statistics of Pringsewu Regency. Apart from that, data were also collected from previous studies that had been conducted previously in several areas in Pringsewu Regency. and other supporting data. Data analysis in qualitative research will take place simultaneously with other parts of the development of qualitative research, namely data collection and writing of findings.

A research certainly requires research data that meet scientific criteria in the form of valid, reliable and objective. So in this study, always check repeatedly and ensure that the research data is in accordance with or in line with the concepts and theories used. Meanwhile, to get the validity of the data, it is done by using the triangulation method, both from informants, data sources, data collection techniques, and research instruments such as descriptions of research in the field. Also, researchers need to test validity with informants to triangulate interview data with field observations. After all these processes have been passed, the data is considered valid when there is no difference between what was reported or written by the researcher and what actually happened to the object of research [15]

\section{RESULT AND DISCUSSION}

\subsection{Dynamics of Transmigration Community Development in Pringsewu District}

The first transmigration occurred in 1905 when the Dutch came to power in Indonesia. The area where the Transmigrants came first was the southern part of Sumatra, precisely in the area of Lampung Province now. At that time, the first ethnic group to transmigrate was the Javanese who were placed in the Gedong Tataan area, Pesawaran Regency, Lampung Province before Indonesia's independence. The arrival of the transmigration was a manifestation of the politics of return (ethical politics) of the Dutch kingdom to their colonies, including the Dutch East Indies, Indonesia today. The transmigrant communities were originally brought in by the Dutch East Indies government to open plantation land as well as as labor workers in the transmigrant area [15]; [2].

In its development, the transmigration program was stopped by the Dutch East Indies government, but was resumed due to the economic crisis that caused riots on the island of Java in 1937 [15]. In fact, one of the informants explained that the initial relocation of residents (transmigrants) was done to break the power of Prince Dipenogoro's followers who at that time were fighting against the Dutch East Indies government [3].

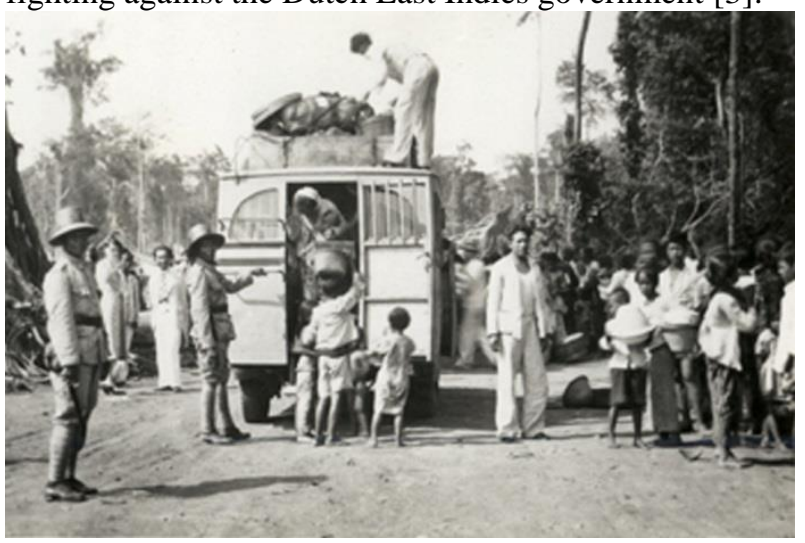

Figure 2 Pictures of the arrival of Javanese Ethnic transmigration

(Source:

https://www.pringsewukab.go.id/pages/sejarah-

kabupaten-pringsewu accessed on August 26, 2020).

From the first exodus, then continued with the next transmigration program. Where the spirit of the first movement to provide workers on the plantations of the Dutch then turned into a population movement with the spirit of equality and prosperity during the Old Order and New Order administrations [15]. In addition, community mobility has begun to develop, in Java, causing non-formal migration to occur. This type of transmigration is a voluntary migration, in which the arrival of the migrant community is carried out of their own volition (swakarsa transmigration), which in its development continues to increase in number [16]. Especially young people who have the passion to find work. This of course causes migration to continue to occur, thus contributing to increasing the number of Javanese in the Pringsweu area, Lampung Province [3].

The arrival of Transmigration, either formally or on an initiative, certainly has an impact on the indigenous people. Ethnics who were originally laborers or workers in the plantation area of the Dutch and on plantations or agriculture belonging to the indigenous people, turned into a community that has resources. Indeed, in historical reality the Javanese had land that was given by the government at that time. But of course not many and limited owned by ethnic Javanese who follow the trend of formal migrants. Therefore, these self-sufficient 
transmigrations certainly have the land from their hard work. Either through buying or giving in return for their services. Thus, it can be ascertained that the ownership of these resources is purely due to their hard work in working and trying [17].

From the ownership of resources in the form of land, they are able to survive without being laborers. With the ownership of the land, they also have more income and are able to survive in the Pringsewu area. So, because they are able to survive and adapt to their new environment, it makes them change in their old social life, and survive with their new social life [18];[19];[2] .

In addition, the informant said that the social life of the Javanese Ethnic community is growing rapidly. The development process began when the Lampung Ethnic community continued to employ Javanese Ethnics. Interaction occurs internally, not only through the relationship between workers and landlords. The relationship developed into the social life of the two ethnicities. The relationship that exists is not only when the Javanese are working on the land owned by the Lampung Ethnic, but has entered the social and cultural sphere. By that tap, the acculturation of the two ethnicities occurred, so that in its development, the relationship between landlords no longer existed, but developed into a relationship of co-workers who need each other [17] [5]; [18]; [19]; [2]

This certainly makes social, cultural, economic, and political changes occur in the Pringsewu area. Of course the change occurred because of a mutual understanding that was not written and developed without them realizing it. This change occurred through the existence of social exchanges between the Javanese ethnic community and the indigenous ethnic group. Of course, the exchange has the same value to be exchanged. That is, the interests obtained and expected are balanced, both material interests such as goods and services, or immaterial such as social values [20]; [21]; [22]; [23] [2].

\subsection{The Integrative Reality of Ethnicity in Pringsewu}

The presence of transmigrants from other islands to Lampung Province generally provides opportunities for social change between different ethnic groups. This change occurred due to the ability of the migrant community to adapt in their new area as a group of migrants characterized by transmigrants. In addition, the openness of perspective of the indigenous ethnic community, namely Lampung provides an opportunity for the creation of a multi-ethnic society with an integrative pattern (Observation July 1, 2020).

The integration of the community in the Pringsewu area illustrates that the existence of ethnic groups in Pringsewu Regency which is multi-ethnic can be seen from the differences and diversity in this region. Where these differences can also be seen from differences in culture, religion, language, relations, traditions, group residence, and physical appearance [20]; [21]; [22]; [23];[19]. In addition, BPS data (2000) which is reinforced by researcher observations (2020) shows that the ethnic groups in the Pringsewu area consist of Javanese, Sundanese, Lampung, Balinese, Batak, Palembang and a small number of ethnic groups. others from outside Lampung Province. In addition, the existence of areas characterized by native villages such as Pardasuka (Lampung) and Gadingrejo (Java) shows ethnic diversity in Pringsewu Regency.

The ethnic diversity certainly has an effect on multiethnic areas, such as Pringsewu. However, when a more dominant positive effect occurs, it is certain that the people in the area are able to integrate well. This ability to integrate will give birth to a new identity that can be grouped into new ethnic groups originating from the same area. Of course that identity is raised and accepted as a distinct characteristic [24]. In the reality of the people in Pringsewu, claims of origin that do not reveal where their ethnic origin is when they are asked where they come from by others, shows that they are able to group them on the basis of the place where they live and develop [25].

Recognition as above certainly raises an identity of community groups whose purpose is to unite each other between groups, so that it will lead to an interaction relationship that results in an understanding of shared norms and values. These values and norms are certainly not always in the form of new values and norms, but also the values and norms held by each ethnic group that are adopted and carried out by other et [21]. Things like this are certainly found in the research area inhabited by indigenous ethnic groups. The initial development of values and norms originates from the original ethnicity, but develops into new values when ethnic immigrants develop into the majority ethnic in the area. This can be seen from the language and marriage customs, where the ethnic groups in the region use a new method of reception without leaving their original characteristics, such as how to dress and talk [26].

The emergence of new norms and values also shows the occurrence of integration in an ethnically diverse society. This integration also proves that the people in the Pringsewu area can accept each other's differences. The acceptance of each other's differences certainly results in compromises as a middle ground, thus creating a peaceful society. Public peace is not obtained just like that, but there are unwritten agreements in society that run without realizing it. The form of this awareness is mutual acceptance with all the differences brought by each ethnic group, which are then merged into one so as to produce a common consensus in the form of integration [2]. 


\subsection{Social Exchange as a Process in Creating Integrative Space}

The presence of different ethnicities in the Pringsewu area raises the dynamics of community development. This dynamic gave birth to integration between immigrant ethnic groups (Javanese ethnicity) and indigenous ethnic groups (Lampung ethnicity). Although the two ethnic groups are culturally different, they can live side by side with each other. This can be seen in the Paraduka area, which is the original village of the Lampung ethnic community. Where this village is able to show that integration occurs in their community. Evidence of their integration is mutual respect and regard for ethnic immigrants (Javanese ethnicity) as part of their community [5].

The above is certainly in line with the expression of [27], which explains that social integration functions to unite various cultural differences within ethnic groups. The goal is to create unity and cooperation between ethnic groups based on cultural norms ( [2].

The existence of a common understanding of integration is certainly carried out through an ongoing process of interaction between members of the Javanese and Lampung ethnic communities. Through these interactions, changes that result in more integrative politics in society are maintained. The ability of the multi-ethnic community in Pringsewu to develop in an integrative way gives them the space to create a peaceful and peaceful society. This development is carried out dynamically following the direction of change in society. Therefore, with the continuous interaction process, the people in Pringsewu can continue to live in society and build patterns of social integration that can create order. Through social life, Javanese Ethnic communities can survive and live in transmigrant areas with the process of getting to know each other, forming social relationships, interacting with each other and producing values, norms, customs, traditions and cultures that they mutually agree on [27]; [2]). Thus, through a life that is built on the basis of the integration of inter-ethnic life, both Javanese and other ethnicities in the Pringsewu area produce a common consensus to reach an understanding to pursue a common goal.

In addition, Koentjaraningrat (1986) reveals that society is formed through a social environment that has its own characteristics. Each member of the community group will be met with various traits and behaviors of other members in the community [21]. In Pringsewu Regency, this is the case, although the majority of ethnic Javanese dominate this region, each member or community group has its own characteristics. This is certainly a difference as well as a challenge in an integrative society. However, the characteristics that produce differences are mutual understanding between members or community groups in Pringsewu Regency. This was achieved due to the adaptation and adjustment of every member of the community in Pringsewu Regency. Ethnic Javanese people who in the majority can understand other ethnicities that are different from their customs and culture as well as their life habits [25].

To continue to create balance, the multi-ethnic community in Pringsewu Regency continues to have reciprocal relationships. The goal is to create harmony, balance and peace between people of different ethnicities. Through the reciprocal activities of each ethnic member, both Javanese and other ethnic groups, they feel that they need each other. This reciprocal process is part of the model of social interaction, where reciprocal activities are part of the process of social exchange in society. Therefore, with this exchange, the needs in society can be achieved by each member of the community group [33].

In this social exchange, of course, every component in society can be used as a subject or object of exchange. Either the subject or object is an object or something else. The two certainly have a very clear relationship in the exchange process. Exchange is not only limited to a relatively small social aspect, but also in a wider realm, including identity politics. In addition, the exchanged subjects do not limit themselves to the exchange model or the object of exchange, so that in the exchange process there are social values embedded in each exchanging subject, so that these social values bring benefits (benefits) for the ethnic groups in the community. Pringsewu, including in terms of politics [5]. The benefits of social exchange based on social values can certainly be in the form of short-term or long-term exchanges [28]; [29];[30];[31].

In fact, Ritzer (2012) states that social exchange is not only carried out in the economic aspect, but also in the power aspect [34]. So, this certainly has implications in the political field. Of course, if the exchange is used in a political context, it will produce less friction, because the exchange occurs voluntarily and without coercion [19]). Therefore, social exchange in society can be used as an interaction process that can generate political benefits between the people who carry out the exchange.

In addition, the communities in Pringsewu carry out exchanges with other ethnic groups in the simplest terms, such as giving something from plantation products to, for example, not only to the same ethnic group as themselves. But also to a different ethnic group from him. Of course, in an activity like this, the reward given by each individual is different, the person who gives it gets trust or reciprocity of social value, while the person who gets the gift gets the object he needs. In an exchange process like this, both parties who exchange mutually gain profits for themselves [33].

The concept of social exchange is a process in forming a space for social integration in society. Where the exchanged ethnic groups carry out social processes in interacting in a way that they think is acceptable in the community. The rewards in the exchange process 
are perceived as a reward between the ethnic groups who make the exchange. Thus, at the same time it will strengthen social ties in relations between communities and create a sense of mutual understanding ( [32]; [19]. With these strong ties, the Javanese and other ethnic groups have merged by reducing the gap between ethnicities, making it easier to achieve goals, including political goals.

Therefore, social exchange is used as a social tool to achieve a desired outcome peacefully. Thus, through the process of social exchange that is carried out voluntarily, it will form a community integration [33]. From the social integration resulting from these social exchanges, the Javanese were able to create political space for their ethnicity, resulting in a new administrative area. Where, those who were originally a third-class society were then able to proceed to become an ethnic group that was successful in the political field. The birth of Pringsewu Regency as a new administrative area for the Javanese Ethnic community can be used as an illustration of political success through the process of social exchange. This process can be claimed as a political identity that they can produce sociologically.

\subsection{Integrative Politics as Javanese Ethnic Political Identity in Pringsewu District}

The formation of the administrative area of the Pringsewu Government is proof that Pringsewu Regency was formed because of the integration between different ethnic groups. This is because, Pringsewu Regency is occupied by people who previously transmigrated from other ethnically different areas, one of which was the Jaw Ethnic [2]. The development of Pringsewu Regency as one of the areas occupied by the Javanese ethnicity in the majority. Then their ability to organize their identity so as to form a new political power, proves that they are able to adapt to their environment, so that the adaptation results provide social change to the community [7].

The birth of Pringsewu Regency as an administrative area has become its own specialty for the Lampung Province. This is of course because Pringsewu Regency is the only area occupied by the majority of transmigrants and is able to establish an administrative area with a name identical to that of the transmigrant ethnic group. In addition, all research informants revealed that, when they were asked about what was known about Pringsewu District, they all answered with Javanese people. This information shows that Pringsewu Regency is indeed identical with the Javanese people who transmigrated to the Lampung Province.

The survival of Pringsewu as an administrative area which incidentally is an area that is synonymous with the name of Java is seen as a political victory for the Javanese people in the Pringsewu area. The establishment of Pringsewu which was carried out without violence or inter-ethnic conflict became a sign that integration in this region was well-rooted in all ethnic communities. The integration process is carried out in various ways, one of the approaches that has been carried out so far is social exchange between ethnicities. The social exchange approach has succeeded in providing a good integration effect in the Pringsewu area. From the results of interviews conducted with the Lampung ethnic who live in the Pardasuka Village area, it shows that the exchange of Javanese and Lampung ethnicities occurred. This exchange resulted in community integration. The exchange is not only about fulfilling economic needs, but also fulfilling the needs of values and norms that produce order and security between existing ethnic groups.

\section{CONCLUSION}

The political identity of Javanese ethnicity is formed through an integrative process of society, both Javanese and other communities. The discovery of this identity is certainly a long process. Social dynamics occur as part of the social integration process of society. The people of Pringsewu Regency find a model of social integration through a process of social exchange between Javanese and other ethnic groups. The success of integration obtained through social exchange produces political power that can be used as a vehicle to strengthen their position. The political power they get is maintained through symbols that contain integrative values. Of course, this form of integration is a manifestation of the compromise they most agree on together. Therefore, the social integration of Javanese ethnicity in Pringsewu district can be used as the political identity of the Javanese ethnic community.

\section{AUTHORS' CONTRIBUTIONS}

The study of the political identity of the Javanese ethnic community is able to contribute ideas in mapping the form of Javanese ethnic political identity within a conceptual/theoretical framework. With this study, it is hoped that it will be able to provide its own discourse in the study of social change and sociology of politics. In addition, this study will give birth to similar studies that have novelty in the academic field.

\section{ACKNOWLEDGMENTS}

Acknowledgments are given to the Department of Sociology, Faculty of Social and Political Sciences, University of Lampung for their scientific support. Thanks are also given to research institutes and services at the University of Lampung for their financial support during this research. 


\section{REFERENCES}

[1] F. Khoiriyah, A. Fahri, B. Bramantio and Sumargono, "Sejarah Toponimi Daerah Transmigrasi Provinsi Lampung Melalui Tuturan Tradisi Lisan," JURNAL AGASTYA, vol. 9, no. 2, pp. 221-240, 2019.

[2] R. Putri, M. F. Nurdin, M. Fedryansyah and Junaidi., "Realitas Dinamika Integrasi Sosial Etnis Jawa dan Lampung di Daerah Pardasuka Kabupaten Pringsewu," JUPIIS: Jurnal Pendidikan Ilmu-Ilmu Sosial, vol. 11, no. 2, pp. 201-212, 2019.

[3] K. M. T. P. Lampung, Interviewee, Sejarah Transmigrasi di Lampung. [Interview]. 2 Juli 2019.

[4] R. B. Prihatin, "Revitalisasi Program Transmigrasi," Aspirasi: Jurnal MasalahMasalah Sosial, vol. 4, no. 1, pp. 57-64, 2013.

[5] K. D. Pardasuka, Interviewee, Sejarah Terbentuknya Kabupaten Pringsewu. [Interview]. 3 Agustus 2019.

[6] Zahrotunnimah, "Sejarah Politik Identitas dan Nasionalisme Di Indonesia," Adalah: Buletin Hukum dan Keadilan, vol. 2, no. 10b, pp. 9394, 2018.

[7] Sukamto, "Politik Identitas (Suatu Kajian Awal dalam Kerangka dan interaksi "Lokalitas dan Globalisasi")," Jurnal Sejarah dan Budaya Universitas Malang, vol. 3, no. 2, pp. 9-23, 2010.

[8] M. Habibi, "Analisis Politik Identitas di Indonesia (Identity Politics in Indonesia)," researchgate, 15 April 2019. [Online]. Available:

https://www.researchgate.net/publication/315 338050. [Accessed 11 Maret 2020].

[9] J.Nasrudin and A. A. Nurdin, "POLITIK IDENTITAS DAN REPRESENTASI POLITIK (Studi Kasus pada Pilkada DKI Periode 2018-2022)," Hanifiya: Jurnal Studi Agama-Agama, vol. 1, no. 1, pp. 34-47, 2018.
[10] M. Haboddin, "Menguatnya Politik Identitas di ranah Lokal," Jurnal Studi Pemerintahan, vol. 3, no. 1, pp. 106-134, 2012.

[11] A. S. Maarif, "Politik Identitas dan Masa Depan Pluralisme Indonesia," in POLITIK IDENTITAS DAN MASA DEPAN PLURALISME KITA, Jakarta, Democracy Project, 2012, pp. 3-30.

[12] Suharno, "Konflik, Etnisitas, dan Integrasi nasiona," in Seminar dan Lokakarya Resolusi Konflik pada Civics Community, Yogyakarta, 2006.

[13] Niswatin and Mahdalena, "Nilai Kearifan Lokal "Subak" sebagai Modal Sosial Transmigran Etnis Bali," JAMAL: Jurnal Akuntansi Multiparadigma, vol. 7, no. 2, pp. 171-188, 2016.

[14] S. Wartiharjono, "Potensi konflik dan pembentukan modal sosial: belajar dari sebuah desa transmigran di Kalimantan Timur," Masyarakat, Kebudayaan dan Politik, vol. 30, no. 2, pp. 84-93, 2017.

[15] J. W. Craswell, Research Design: Pendekatan Metode Kualitatif, Kuantiatif, dan Campuran, 4 ed., Yogyakarta: Pustaka Pelajar, 2018.

[16] S. Purboadiwidjojo, "Mencari Suatu Sisitem untuk Melaksanakan Pemindahan Penduduk secara Besar-besaran," in Transmigrasi di Indonesia 1905-1985, Jakarta, UI-Press, 1986, pp. 8-31.

[17] S. Wirosardjono, "Transmigrasi Swakarsa di Indonesia," in transmigrasi di Indonesia 1905-1981, Jakarta, UI Press, 1986, pp. 298302.

[18] K. D. 1. P. Pardasuka, Interviewee, Perkembangan Masyarakat Etnis Jawa di Prngsewu. [Interview]. 20 Agustus 2019.

[19] K. D. 4. P. Pardasuka, Interviewee, Perkembangan Etnis Jawa di Pardasuka. [Interview]. 2782019.

[20] R. Putri, "Integrasi Sosial antar Etnis dalam Kepemilikan Lahan Pertanian di Desa Pardasuka, Kabupaten Pringsewu," FISIP 
UNPAD, Bandung, 2019.

[21] J. Coleman, The Adolescent Society, New York: Free Press, 1961.

[22] R. Emerson, "Social Exchange Theory," in Social Psychology, New York, Basic Book, 1981, pp. 30-65.

[23] R. Stebbins, Sociology: the Study of Soceity, 2nd ed., New York: Haper and Row, 1990.

[24] I. G. Pitana and .. P. G. Gayatri, Sosiologi Pariwisata: Kajian Sosiologis terhadap Struktur, Sistem, dan Dampak-dampak Pariwisata., Yogyakarta: Andi Yogyakarta, 2005.

[25] P. Ratcliffe, Conceptualizing "Race", Ethnicity and Nation: Towards a Comparative Perspective in Race, Ethnicity and Nation., London: Taylor \& Francise, 2006.

[26] Koentjaraningrat, Pengantar Ilmu Antropologi, 6 ed., Jakarta: Aksara Baru, 1986.

[27] R. J. Feagin, Racial and Ethnic Relation, Prentice Hall, Inc A Simon \& Schuter Company, Engleword Cliffs: New Jersy, 1993.

[28] H. Poerwanto, "Hubungan Antar SukuBangsa dan Golongan Serta Masalah Integrasi Nasional Di Indonesia," Jurnal Ketahanan Nasional, vol. 10, no. 1, pp. 17-31, 2005.

[29] R. Narroll, Kelompok Etnik dan Batasannya, Jakarta: Universitas Indonesia Press, 1964.

[30] T. P. Pardasuka, Interviewee, Sejarah kabupaten Pringsewu. [Interview]. 21 Juli 2019.

[31] A. Amriwan, Interviewee, Perkembangan Kabupaten Pringsewu. [Interview]. 15 July 2020

[32] D. Hendropuspito, Sosiologi Sistematik, Yogyakarta: Kanisius, 1989.

[33] B. Raho, Teori Sosiologi Modern., Jakarta: Prestasi Pustaka, 2007.
[34] G. Ritzer, Teori Sosiologi :Dari Sosiologi Klasik sampai Perkembangan Terkini Postmodern. (, Trans.), 12 ed., Yogyakarta: Pustaka Pelajar, 2012.

[35] P. M. Blau, Exchange and Power in Social Life, New York: Wiley, 1964.

[36] M. Poloma, Sosiologi Kontemporer, Jakarta: PT RajaGrasindo, 200. 